\author{
Milena Papić-Obradović \\ Assistant Research Professor \\ Clinic of Gynecology and Obstetrics - \\ Narodni Front, Belgrade \\ Branislava Jeftić \\ Ph.D. Student \\ University of Belgrade \\ Faculty of Mechanical Engineering \\ Lidija Matija \\ Associate Professor \\ University of Belgrade \\ Faculty of Mechanical Engineering
}

\section{Papanicolaou Stained Cervical Smear Analysis Using Opto-Magnetic Imaging Spectroscopy}

Cervical cancer is the second most common invasive cancer of the female genital tract. In this study, samples prepared for standard Pap test were used and examined using digital imaging software that analyzes the difference between reflected diffuse white light and reflected polarized light (opto-magnetic imaging spectrosopy) in order to detect normal, dysplastic and cancerous cells. A digital camera customized for taking OMIS pictures of samples and light-mater interaction software for optomagnetic image analysis guided the diagnostic decision to more refined distinction between normal smear and the one containing either dysplastic or cancerous cells. Since the application of OMIS enables detection of significant differences between standard Pap test categories, this method offers an advantage over classical methods in the area of early detection of suspicious cells. By this method it is possible to obtain the result that is not dependent on the capability, subjectivity, experience and knowledge of the practitioner.

Keywords: PAP smear, reflected polarized light, digital imaging, spectral convolution, opto-magnetic spectroscopy, cervical cancer detection.

\section{INTRODUCTION}

Cervical cancer is the fifth most common cancer affecting nearly 500,000 women worldwide each year. In less developed countries it is the second most common cancer in women accounting for nearly 300000 deaths every year, $80 \%$ of which occur in less and middeveloped countries [1].

An estimate of diagnosed cases for US has risen from 11,070 for the year 2008 to 11,630 for year 2012. Also, an estimate for death expectancy in US has risen from 3 870 for the year 2008 to 4140 for the year 2012 [2], [3]. Two conclusions can be drawn from these data: 1) the striking discrepancy in number of diagnosed cancers (and cancer deaths) between less developed and industrialized countries is caused by introduction of cytological screening programs in more developed societies in the past few decades, and 2) the slight rise of expectancy figures indicates that cervical cancer is not under control even in highly developed countries, despite the increase in diagnostic measures and introduced vaccination against human papilloma virus (HPV).

Cervical cancer usually develops over a period of more than 10 years pointing to weaknesses related to the sensitivity of cytological screening. Due to extended diagnostic period, interventions on changes that would regress spontaneously are not uncommon, showing that biopsies are often performed on false positive cytology results. All this culminates in finding that frequent testing, follow-up examinations, and excessive

Received: January 2014, Accepted: March 2014

Correspondence to: Branislava Jeftić

Faculty of Mechanical Engineering,

Kraljice Marije 16, 11120 Belgrade 35, Serbia

E-mail: bjeftic@mas.bg.ac.rs

doi:10.5937/fmet1602212P

(C) Faculty of Mechanical Engineering, Belgrade. All rights reserved treatment due to equivocal findings make cervical cancer screening an important cost factor in most healthcare systems.

Two most widely used methods for early detection and screening purposes are the Pap smear test and human papilloma virus DNA test (HPV DNA). In case a patient has been diagnosed with abnormal Pap test results, additional methods are utilized which include visualization of: cervical canal (colposcopy), bladder (cytoscopy), and colon (proctoscopy) to examine the possibility of cancer spreading to surrounding organs. In parallel with these methods, biopsy is often performed to analyze tissue samples.

Since the existing methods have not proven to be sufficiently sensitive and cost-effective, novel approaches are introduced in both modalities, cytological (liquid cytology, ThinPrep) and biomarker methods (HPV RNA, MYC). In search for less expensive and more sensitive methods liquid-based cervical cytology has been introduced offering a picture of the sampled cells that is more consistent and easier to interpret than in conventional smears, and greater ease in standardization and allows for the sampled material to be used for additional biomarker testing.

Subsequently, an array of comparison studies followed, comparing the existing and new methods. Comparison studies of Pap and HPV DNA testing showed greater potential use of HPV testing in screening tests for the detection of intraepithelial neoplasia [4], [5]. Another study, due to encouraging results of HPV tests [6], suggested gradual replacement of all morphological methods based on cytology and histology with HPV testing [7]. However, although HPV infection is a necessary cause of development of cervical cancer, at this stage HPV testing is unable to distinguish between transient HPV infections and 
malignancy, while regressions participate significantly in total number of diagnosed cases [7], [8]. Other studies suggest that joint use of HPV and Pap test could render better results than any of the methods used alone [9], [10].

Therefore, improvements towards increased sensitivity should be proposed and/or introduced. Other variously combined comparison studies correlated other significant methods in terms of sensitivity (HPV DNA, ThinPrep Imager, Liquid and ordinary cytology).

These results signal that improvement of Pap method is needed in terms of increasing its sensitivity. Some attempts are already underway. Two studies have compared the method of Automated ThinPrep Imaging System (TIS) to manual examination [11], and application of TIS in comparing liquid based versus conventional cytology [12] showing that TIS detects 1.29 more cases of histological high grade squamous disease per 1000 women screened than conventional cytology (given that cervical intraepithelial neoplasia grade 1 has been taken as the threshold for referral to colposcopy).

Our study introduces a new method, optomagnetic imaging spectroscopy (OMIS) based on digital recording light-matter interaction using standard Pap smear slides and customized digital camera. This method can examine the whole slide and does not necessitate image segmentation that can increase processing time. However, if desired, appropriate parts of slides may and can be excluded from the rest of the sample to eventually render more efficient guidance to the diagnostic procedure.

In addition to customized camera, a software solution is used for analysis of obtained images, yielding a characteristic diagram - diagnostic result - showing the intensities of light in correspondence with wavelength difference. The OMIS method has been used in studies to characterize properties of water [13,14], skin [15], materials for contact lenses [16] and Epstein - Barr virus detection in blood plasma samples [17].

\section{MATERIALS AND METHODS}

For this study we have gathered a total of 120 Pap staining smear slides which were categorized by standard Pap test examination into four groups (II normal with non-typical inflammation, 30 cases, III dysplasia, 30 cases, IV - carcinoma in situ, 30 cases, V - suspicion to carcinoma, 30 cases).

We used a novel opto-magnetic imaging spectroscopy (OMIS) method which is based on electron properties of matter (covalent bonds, hydrogen bonds, ion-electron interaction, Van der Walls interaction) $[13,18,21]$. The method was originally developed for early skin cancer and melanoma detection. [19]. Bearing in mind that the orbital velocity of valence electron in atoms is about $10^{6} \mathrm{~m} / \mathrm{s}$, it gives ratio between magnetic force $\left(F_{M}\right)$ and electrical force $\left(F_{E}\right)$ of matter for about $F_{M} / F_{E} \approx 10^{-4}$. Since force $(F)$ is directly related to quantum action (Planck's action, $h=$ $\left.F \times d \times t=6.626 \times 10^{-34} \mathrm{Js}\right)$ it means that the magnetic force is four orders of magnitude closer to quantum action and detecting the conformation change of matter than the electrical force [20]. When a picture of a surface is taken with classical optical microscope the obtained image is a product of electromagnetic properties of light, while OMIS is based on difference between diffuse white light (similar to daylight) and reflected polarized light. This type of light is produced when source of diffuse light irradiates the surface of matter under a certain angle. Each type of matter has a specific angle of polarized light. Since reflected polarized light contains electrical component of lightmatter interaction, calculating the difference between white light (electromagnetic) and reflected polarized light (electrical) gives the magnetic properties of lightmatter interaction.

Since we used digital images in RGGB (red, greengreen, blue) system, we chose basic data in red and blue channels for white diffuse light and reflected polarized white light. Algorithm for data analysis is based on "Maxwell triangle" chromaticity diagram and spectral convolution according to ratio of (R-B)\&(W-P), which means that red minus blue wavelength of white and reflected light will give: Reflected white light minus Reflected polarized light is equal Magnetic fingerprint of matter [21].

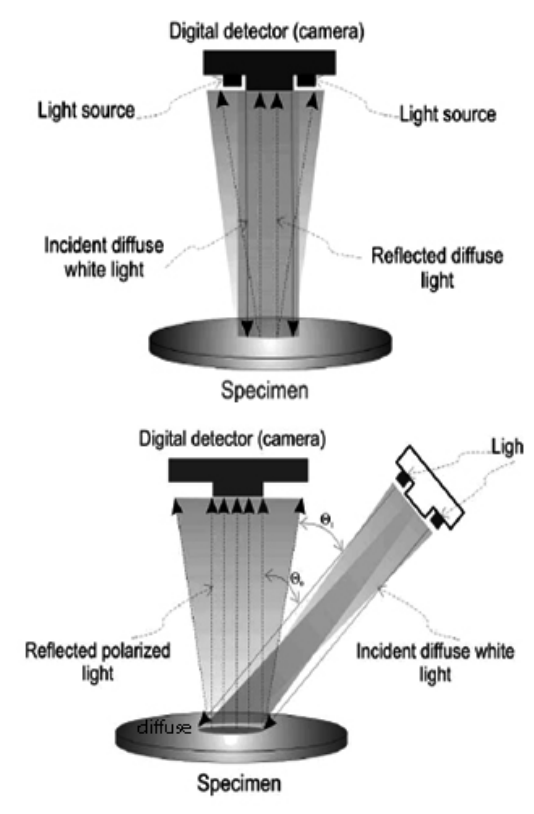

Figure 1. Incident white light will give different information about sample surface properties, when reflected, depending on the angle of incidence. Each type of matter is characterized with a specific angle of incidence [21].

\section{RESULTS}

Some typical digital images of Pap samples (group II) obtained with diffuse white light and reflected polarized light are selected and shown in figures $2 \mathrm{a}$ and $2 \mathrm{~b}, 3 \mathrm{a}$ and $3 \mathrm{~b}, 4 \mathrm{a}$ and $4 \mathrm{~b}$, respectively. Observation of these images with naked eye would clearly testify no difference between them. However, using computer assisted analysis (CAA) based on spectral convolution algorithm (SCA) we have extracted some interesting differences whose final results are shown on corresponding diagrams (figures $2 \mathrm{c}, 3 \mathrm{c}$, and $4 \mathrm{c}$ ). In spite that digital images on figures 2, 3, and 4 are different, their OMIS diagrams look surprisingly similar, almost the same. In all three cases we observe four peaks, two of them 
having very similar positive intensity values $(105 \mathrm{~nm}$ and $123 \mathrm{~nm}$ ) and two with negative intensity value (109 $\mathrm{nm}$ i $126 \mathrm{~nm})$. These values are valid for spectral convolution field. They are symmetrical and indicate normal tissue state. The reason for this is same Pap group, which is in this case normal.
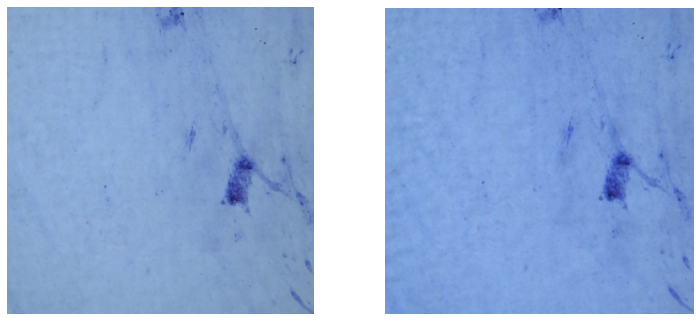

Figure 2a, b. Digital image of a Pap smear slide categorized as group II (normal tissue state with non-typical inflammation): a) diffuse white light (left), b) reflected polarized light (right).

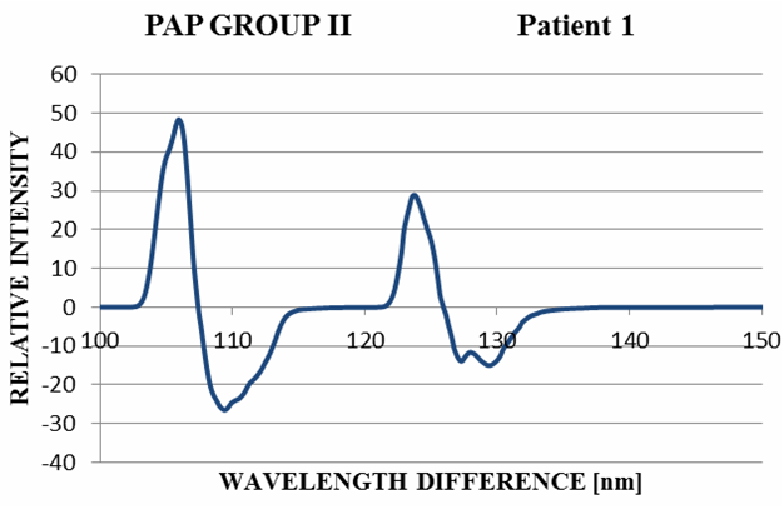

Figure 2c. OMIS diagram of a Pap smear slide categorized as group II (normal tissue state with non-typical inflammation) obtained from images $2 a, b$.
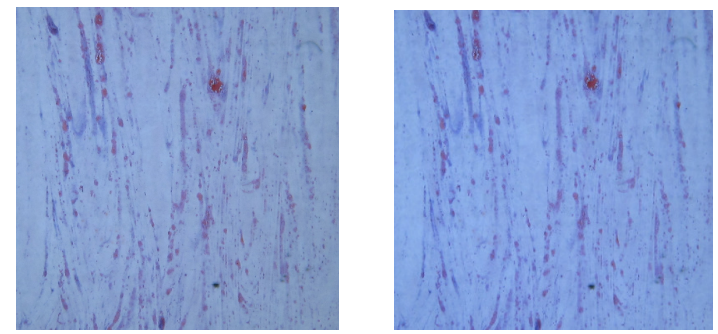

Figure 3a, b. Digital image of a Pap smear slide categorized as group II (normal tissue state with non-typical inflammation): a) diffuse white light (left), b) reflected polarized light (right).

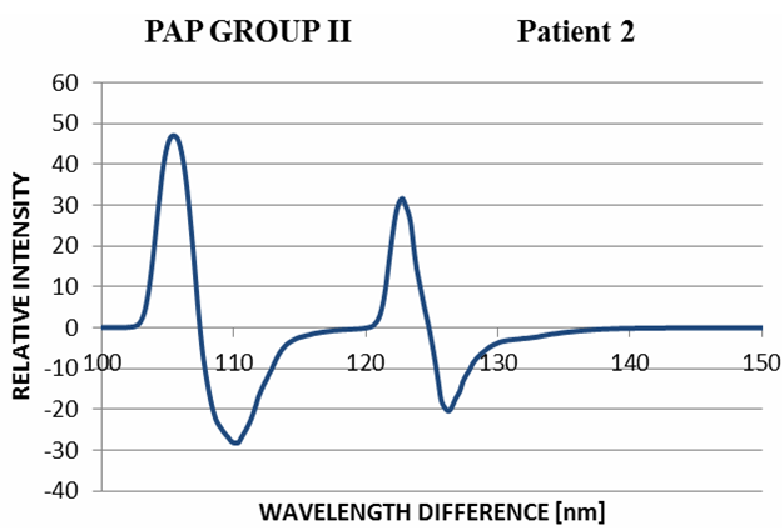

Figure 3c. OMIS diagram of a Pap smear slide categorized as group II (normal tissue state with non-typical inflammation) obtained from images $3 a, b$.
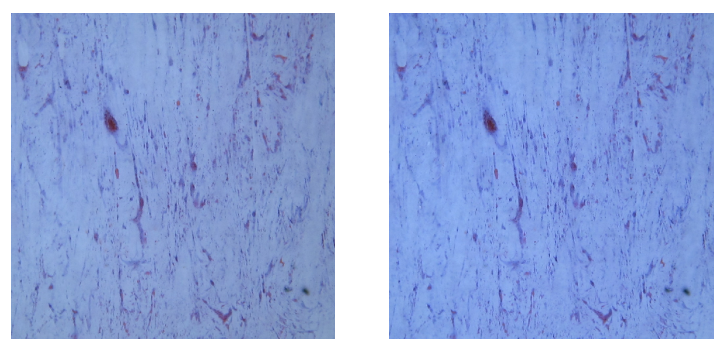

Figure 4a, b. Digital image of a Pap smear slide categorized as group II (normal tissue state with non-typical inflammation): a) diffuse white light (left), b) reflected polarized light (right).

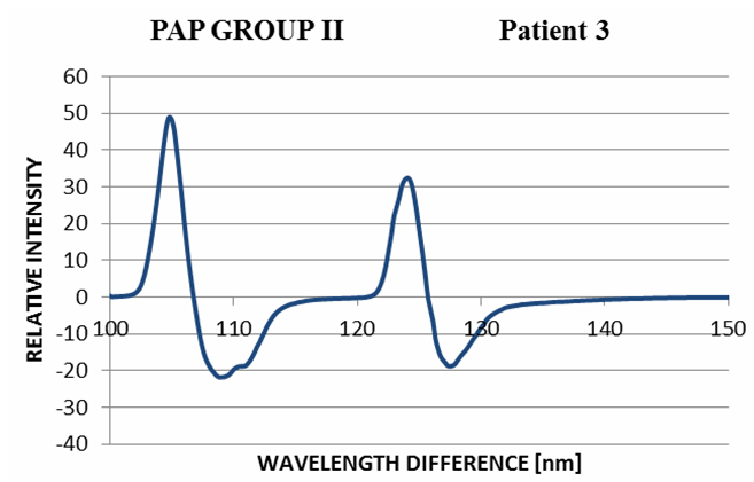

Figure 4c. OMIS diagram of a Pap smear slide categorized as group II (normal tissue state with non-typical inflammation) obtained from images $4 a, b$.

However, the similarity of OMIS diagrams for samples categorized as group III (dysplasia) is not nearly ubiquitous as for group II (normal tissue state with non-typical inflammation). For group III (dysplasia) there are significant differences between samples. The reason for this is because there is different intensity of dysplasia (week, middle, strong). All samples are from one group but with diversity from case to case: there is change in peak intensity and small difference in peak position.

\section{PAP GROUP III}

Patient 4

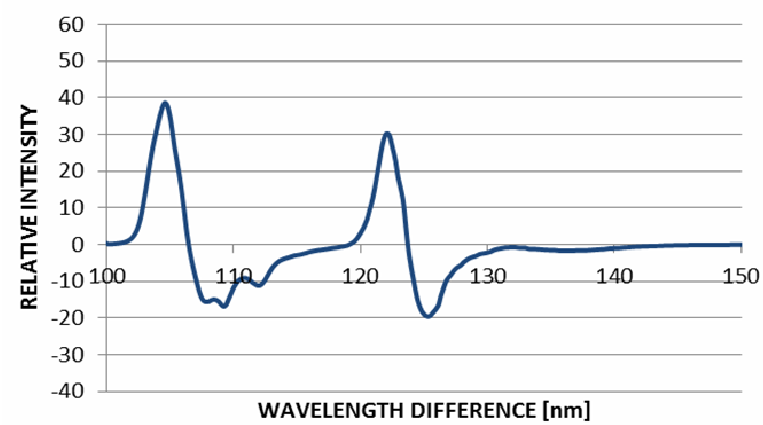

Figure 5. OMIS diagram of a Pap smear slide categorized as group III (dysplasia).

All higher order Pap groups are described with distinctive diagrams depicting their own characteristic intensity to wavelength relationship. The most important remark is that these patterns differ in an easily detectable manner. The diagram for group III shown in figure 5 has four peaks, belonging to following wavelengths: $104 \mathrm{~nm}, 108 \mathrm{~nm}, 122 \mathrm{~nm}$ and $125 \mathrm{~nm}$. Peaks have intensities and wavelengths whose distribution differs from that of group II. The same kind of analysis can be conducted in a straightforward 
manner for the sample diagram in group IV (carcinoma in situ), shown on Figure 6. The four peaks for group IV differ from figure 5 in intensities and also possess a slight shift in corresponding wavelengths (103 nm, 106 $\mathrm{nm}, 120 \mathrm{~nm}, 123 \mathrm{~nm}$ ). First peak with positive intensity value decreases in higher order Pap groups.

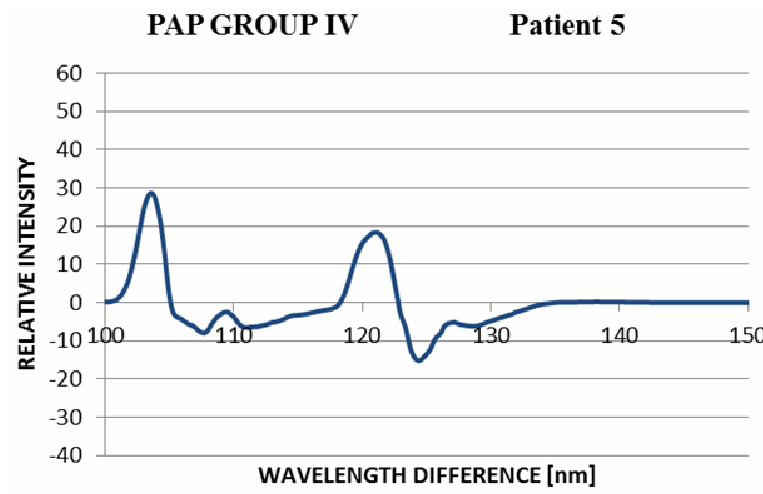

Figure 6. OMIS diagram of a Pap smear slide categorized as group IV (carcinoma in situ).

OMIS diagrams for samples categorized as group V (suspicion to carcinoma) share some qualitative similarity but differ markedly from groups II, III, and IV. Looking at figure 7 we observe a quite different diagram pattern. The difference is obvious not only in number of peaks, but also in peak intensity that is noticeably lower than intensity of typical peaks in diagrams representing II, III and IV Pap group. The patterns are unseen in lower grade groups and are likely to be produced by malignant cells.

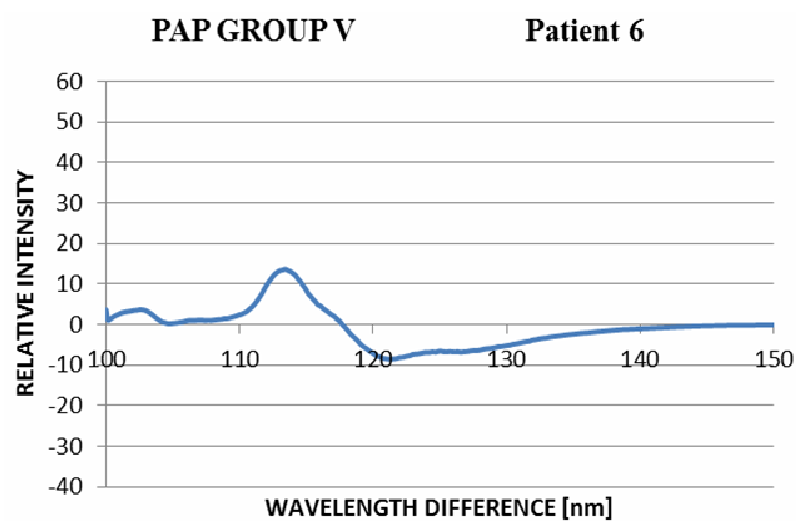

Figure 7. OMIS diagram of a Pap smear slide categorized as group V (suspicion to carcinoma).

\section{DISCUSSION}

Despite the increase in variety of diagnostic methods we are still a long way from bringing cervical cancer rates under control. As a result, both vaccinated and unvaccinated women must continue to undergo routine cervical cancer screening. This fact is already established and current research is directed to finding a most cost-effective method.

Introduction of a variety in diagnostic methods has not initially improved the efficiency of cervical cancer screening since most of those methods are treated in research and literature as competing and mutually exclusive. In rare, promising, cases these methods are seen as complementary.
Fortunately, most new proposals for optimal screening method are based on multi-level concepts e.g. primary screening with high sensitivity followed by a specific test to clarify equivocal findings. At present, in addition to cytology represented by Pap smear test, HPV DNA testing is the only method with enough data to support its use as part of primary screening.

The goal of this study is to use the standard Pap test and improve its efficacy by providing means for more rapid and accurate prediction potential. The two way improvement includes: 1) rapid diagnosis enabled by examination of the whole slide, without the need for image segmentation (however, image segmentation is not excluded as an option to improve accuracy, in this stage it is not a necessary condition) that could eventually serve as a good basis for automation of diagnostic process; 2) increase in sensitivity due to efficient capturing of light interaction through the convolution field. With regards to increase sensitivity our method offers several prospective parameters that could independently contribute to greater accuracy improvement of Pap smear tests. They are: wavelength, intensity of peaks along with their distribution and shape.

Our future work is directed towards examining a wider range of wavelength differences that is coupled with encompassing a larger experimental group. These two aspects could contribute by finding larger area that is sensitive to tissue changes and will enable us to conduct a more objective systematization of the results and fully appreciate the possibilities that are offered.

Novel method and device open possibilities to improve sensitivity, specificity and accuracy in cervical cancer diagnosis.

\section{ACKNOWLEDGMENT}

This work is supported by Ministry of Education, Science and Technological Development SR Serbia, project III41006. Also, we are grateful for the assistance of the staff from the Clinic for Gynecology and Obstetrics "Narodni front" Belgrade, in collecting data.

\section{REFERENCES}

[1] Waggoner, E.S.: Cervical cancer, The Lancet, 361, 9376; ProQuest Nursing \& Allied Health Source, pg. 2217, 2003.

[2] American Cancer Society, Cancer Facts \& Figures 2008, Atlanta: American Cancer Society; 2008.

[3] American Cancer Society, Cancer Facts \& Figures 2008, Atlanta: American Cancer Society; 2009.

[4] Mayrand, M.H., et al.: Human Papillomavirus DNA versus Papanicolaou Screening Tests for Cervical Cancer, The New England Journal of Medicine, Vol. 357, No. 16, 2007.

[5] Arbyn, M., et al.: Virologic Versus Cytologic Triage of Women With Equivocal Pap Smears: A Meta-analysis of the Accuracy To Detect HighGrade Intraepithelial Neoplasia, Journal of the National Cancer Institute, Vol. 96, No. 4, 2004.

[6] Ratnam, S., Franco, E.L., Ferenczy, A.: Human Papillomavirus Testing for Primary Screening of Cervical Cancer Precusors, Cancer Epidemiology, 
Biomarkers \& Prevention, Vol. 9, pp. 945-951, 2000.

[7] Schiffman, M., Castle, P.E., Jeronimo, J., Rodriguez, A.C., Wacholder, S.: Human papillomavirus and cervical cancer, The Lancet, Vol. 370, pp. 890-907, 2007

[8] Cogliano, V., Baan, R., Straif, K., Grosse, Y., Secretan, B., El, G.F.: Carcinogenicity of human papillomaviruses, Lancet Oncol, Vol. 6, 204, 2005.

[9] Mandelblatt, J.S., Lawrence, W.F., Womack, S.M.: Benefits and Costs of Using HPV Testing to Screen for Cervical Cancer, JAMA, Vol. 287, No. 18, pp. 2372-2381, 2002.

[10] Lorincz, A., Richart, R.M.: Human Papillomavirus DNA Testing as an Adjunct to Cytology in Cervical Screening Programs, Arch Pathol Lab Med, Vol. 127, pp. 959-968, 2003.

[11]Davey, E., Irwig, L., Macaskill, P., Chan, S.F.: Accuracy of reading liquid based cytology slides using the ThinPrep Imager compared with conventional cytology: prospective study, British Medical Journal, Vol. 335, 31, 2007.

[12] Biscotti, C.V., Dawson, A.E., Dziura, B., Galup, L.: Assisted Primary Screening Using the Automated ThinPrep Imaging System, Am J Clin Pathol, Vol. 123, pp. 281-287, 2005.

[13] Koruga, Đ., Miljković, S., Ribar, S., Matija, L., Kojić, D.: Water Hydrogen Bonds Study by OptoMagnetic Fingerprint, Acta Physica Polonica A, Vol. 117, No. 5, pp. 777-781, 2010.

[14] Matija, L., Tsenkova, R., Miyazaki, M., Banba, K., Muncan, J.: Aquagrams: Water Spectral Pattern as Characterization of Hydrogenated Nanomaterial, FME Transactions, Vol. 40, No. 2, pp. 51-56, 2012.

[15] Koruga, Dj., Bandić, J., Janjić, G., Lalović, C., Munćan, J., DobrosavljevićVukojević, D.: Epidermal layers characterisation by opto-magnetic spectroscopy based on digital image of skin, Acta Physica Polonica A, Vol. 121, No. 3, pp. 11111115, 2012.

[16] Stamenković, D., Kojić, D., Matija, L., Miljković, Z., Babić, B.: Physical Properties of Contact Lenses Characterized by Scanning Probe Microscopy and OptoMagnetic Fingerprint, International Journal of Modern Physics B, Vol. 24 (6-7), pp.825-834, 2010.

[17] Papić-Obradović, M., Kojić, D., Matija, L.: OptoMagnetic Method for Epstein - Barr Virus and Cytomegalovirus Detection in Blood Plasma
Samples, Acta Physica Polonica A, Vol. 117, No. 5, pp. 782-784, 2010

[18] Persoon, T.J., Sue Zaleski, M., Cohen, M.B.: Improving Pap Test Turnaround time Using External Benchmark Data and Engineering Process Improvement Tools, Am J Clin Pathol, Vol. 118, No. 527-533, 2002.

[19] Koruga, Dj., Tomic, A., Ratkaj, Z., Matija, L.: Classical and Quantum Information Channels in Protein Chain, Materials Science Forum, Vol. 518, pp. 491-496, 2006

[20] Matija, L., Koruga, Dj.: Value of action as a criteria for classical and quantum consideration on molecular level, Proceedings $1^{\text {st }}$ International Congress of Serbian Society of Mechanics, Ed.Šmarac, D. and Kuzmanović, D., pp. 897-902, 2007.

[21] Koruga, Dj., Tomic, A.: Method and algorithm for analysis of light-matter interaction based on spectral convolution, US Pat. App. No..12/350164, US Patent Publication No. 2009/0245603, Pub date October 1, 2009.

\section{АНАЛИЗА ОБОЈЕНИХ ПАПАНИКОЛАУ РАЗМАЗА КОРИШЋЕЊЕМ ОПТО-МАГНЕТНЕ ИМИЏИНГ СПЕКТРОСКОПИЈЕ}

\section{Милена Папић-Обрадовић, Бранислава Јефтић, Лидија Матија}

Карцином грлића материце је други по реду најчешћи облик инвазивног карцинома код жена. У овој студији, узорци припремљени за стандардни Пап тест су испитивани имиџинг софтвером који анализира разлику између рефлектоване дифузне беле светлости и рефлектоване поларизоване светлости (опто-магнетна имиџинг спектроскопија) у циљу детектовања нормалних ћелија, диспластичних ћелија и ћелија канцера. Дигитална камера прилагођена за прикупљање ОМИС слика узорака и софтвер за анализу опто-магнетних слика омогућили су добијање финијег раздвајања нормалних налаза од оних који садрже диспластичне ћелије или ћелије канцера. $\mathrm{C}$ обзиром да ова метода детектује значајне разлике између стандардних Пап категорија, показана је њена предност у односу на конвенционалне методе за рану детекцију канцера. Опто-магнетна имиџинг спектроскопија даје резултате који нису зависни од стручности, субјективности и искуства практичара. 